\title{
Pengetahuan Wanita Usia 45-55 Tahun Tentang Menopause Di Desa Huta Koje Kecamatan Padangsidimpuan Tenggara Kota Padangsidimpuan Tahun 2020
}

\author{
Siti Arafah Julianty Harahap ${ }^{1}$, Ade Puspa Hasibuan ${ }^{2}$ \\ ${ }^{1,2}$ Program Studi Diploma III Keperawatan, Institut Teknologi dan Kesehatan Sumatera Utara.
}

\begin{tabular}{|c|c|}
\hline Info Artikel & A B S T R A K \\
\hline Article history: & \multirow{16}{*}{$\begin{array}{l}\text { Menopause merupakan suatu fase alamiah yang akan dialami oleh setiap } \\
\text { wanita yang biasanya terjadi diatas usia } 40 \text { tahun. Wanita dikatakan } \\
\text { Menopause bila siklus menstruasinya telah berhenti } 1 \text { bulan. Berhentinya haid } \\
\text { tersebut akan membawa dampak pada konsekuensinya kesehatan,baik fisik } \\
\text { maupun psikis. Perubahan paling banyak terjadi pada wanita karena pada } \\
\text { proses menua terjadi suatu fase yaitu fase menopause. Sebelum terjadi fase } \\
\text { menopause biasanya didahului dengan fase premenopause dimana fase } \\
\text { premenopause ini terjadi peralihan dari masa subur menuju masa tidak adanya } \\
\text { pembuahan.Penelitian ini bertujuan untuk mengetahui Pengetahuan Wanita } \\
\text { Usia } 45-55 \text { Tahun Tentang Menopause Di Desa Huta Koje Kecamatan } \\
\text { Padangsidimpuan Tenggara Kota Padangsidimpuan.Dapat diukur dengan } 3 \\
\text { kategori yaitu pengetahuan baik, cukup, dan kurang.Metode yang digunakan } \\
\text { adalah metode kuantitatif dengan desain deskriptif dengan menggunakan } \\
\text { kuesioner tentang karakteristik berdasarkan pendidikan, pekerjaan, dan } \\
\text { sumber informasi. Penelitian ini dilakukan pada } 46 \text { wanita sebagai sampel } \\
\text { yang diambil dari tehnik door to door. Hasil penelitian ini disajikan distribusi } \\
\text { frekuensi dan persentase. Dari hasil penelitian menemukan bahwa } \\
\text { pengetahuan responden berpengetahuan baik } 3 \text { orang (7\%), berpengetahuan } \\
\text { cukup } 19 \text { orang (41\%), berpengetahuan kurang } 24 \text { orang (52\%). Maka } \\
\text { disimpulkan bahwa Pengetahuan Wanita Usia } 45-55 \text { Tahun Tentang } \\
\text { Menopause Di Desa Huta Koje Kecamatan Padangsidimpuan Tenggara Kota } \\
\text { Padangsidimpuan Tahun } 2020 \text { mayoritas pengetahuannya Kurang. }\end{array}$} \\
\hline Diterima 19-06-2021 & \\
\hline Revisi 29-06-2021 & \\
\hline Disetujui 27-07-2021 & \\
\hline Kata kunci: & \\
\hline Pengetahuan, & \\
\hline Wanita, & \\
\hline Menopause. & \\
\hline & \\
\hline & \\
\hline & \\
\hline & \\
\hline & \\
\hline & \\
\hline & \\
\hline & \\
\hline
\end{tabular}

This is an open access article under the CC BY-SA license.

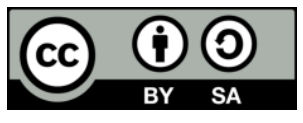

\section{Koresponden Penulis:}

Siti Arafah Julianty Harahap,

Program Studi Diploma III Kebidanan, Institut Teknologi dan Kesehatan Sumatera Utara,

Jl. Trans Sumatera Bukittinggi - Padang Sidempuan, Sihitang, Padangsidimpuan Tenggara, Kota Padang

Sidempuan, Sumatera Utara 22733.

Email: siti_arafah88@yahoo.com

\section{PENDAHULUAN}

Menopause merupakan suatu fase alamiah yang akan dialami oleh setiap wanita yang biasanya terjadi diatas usia 40 tahun. Wanita dikatakan Menopause bila siklus menstruasinya telah berhenti 1 bulan.Berhentinya haid tersebut akan membawa dampak pada konsekuensinya kesehatan,baik fisik maupun psikis. Perubahan paling banyak terjadi pada wanita karena pada proses menua terjadi suatu fase yaitu fase menopause. Sebelum terjadi fase menopause biasanya didahului dengan fase premenopause dimana fase premenopause ini terjadi peralihan dari masa subur menuju masa tidak adanya pembuahan (Aulia, 2009).

Menurut data WHO, jumlah wanita menopause di Asia pada tahun 2025 diperkirakan melonjak dari 107 juta jiwa akan menjadi 373 juta jiwa. Diperkirakan penduduk Indonesia pada tahun 2020 akan mencapai 262,6 juta wanita dengan jumlah wanita yang hidup dalam usia menopause 
sekitar 30,3 juta jiwa dengan usia rata-rata 49 tahun yang mengalami menopause. Saat ini, menurut Depkes RI umur harapan hidup (UHH) perempuan Indonesia adalah 67 tahun. Perempuan Indonesia yang memasuki masa menopause pada tahun 2010 sebanyak 7,4\% dari populasi. Jumlah tersebut akan diperkirakan meningkat menjadi $11 \%$ pada tahun 2015 dan naik lagi sebesar 14\% pada tahun 2025. Berdasarkan hasil penelitian Departemen Obstetri dan Ginekologi di Sumatera keluhan masalah kesehatan yang dihadapi oleh perempuan menopause yaitu perubahan fisik diantaranya keluhan nyeri senggama (93,33\%), Perdarahan pasca senggama (84,44\%), Vagina kering $(93,33 \%)$, Keputihan $(75,55 \%)$, dan gatal pada vagina $(88,88 \%)$.

Di Indonesia rata-rata usia menopause 47 tahun sbelum tahun 2015, pada tahun 2019 ratarata usia menopause menjadi 51 tahun (Kemenkes, 2019). Di provinsi Sumatera Utara jumlah penduduk wanita di Sumatera Utara pada tahun 2016 bejumlah 7.065.585 jiwa, dengan jumlah penduduk wanita menurut kelompok usia 50 tahun keatas yang sudah menopause sebanyak 1.195.016 jiwa (Sumut. Bps. 2018).

Berdasarkan survey awal yang dilakukan peneliti di Desa Huta Koje Kecamatan Padangsidimpuan Tenggara Kota Padangsidimpuan terdapat 46 wanita yang sudah berusia 45-55 tahun dan peneliti sudah mewawancari 5 dari 46 wanita yang sudah berusia 45-55 tahun yang mengatakan tidak mengetahui tentang tanda dan gejala menopause. Untuk itu peneliti tertarik untuk meneliti tentang "Pengetahuan Wanita Usia 45-55 tahun tentang Menopouse di Desa Huta Koje Kecamatan Padangsidimpuan Tenggara Kota Padangsidimpuan Tahun 2020”.

\section{METODE PENELITIAN}

Tabel 1. Distribusi Frekuensi dan Persentase Responden Tentang Pengetahuan Wanita Usia 45-55 Tahun Tentang Menopause Di Desa Huta Koje Kecamatan Padangsidimpuan Tenggara Kota Padangsidimpuan Tahun 2020.

\begin{tabular}{|c|c|c|c|}
\hline No. & & Pengetahuan & Persentase \\
\hline 1. & Baik & 3 & $7 \%$ \\
\hline 2. & Cukup & 19 & $41 \%$ \\
\hline 3. & Kurang & 24 & $52 \%$ \\
\hline & JUMLAH & 46 & $100 \%$ \\
\hline
\end{tabular}

Dari tabel diatas dapat dilihat bahwa dari 46 responden yang diteliti didapat nilai tertinggi berpengetahuan kurang yaitu 24 orang (52\%), pengetahuan cukup 19 orang $(41 \%)$ dan nilai terkecil memiliki pengetahuan baik 3 orang $(7 \%)$.

Tabel 2. Distribusi Frekuensi dan Persentase Responden Berdasarkan Pendidikan Tentang Pengetahuan Wanita Usia 45-55 Tahun Tentang Menopause Di Desa Huta Koje Kecamatan Padangsdimpuan Tenggara Kota PadangsidimpuanTahun 2020.

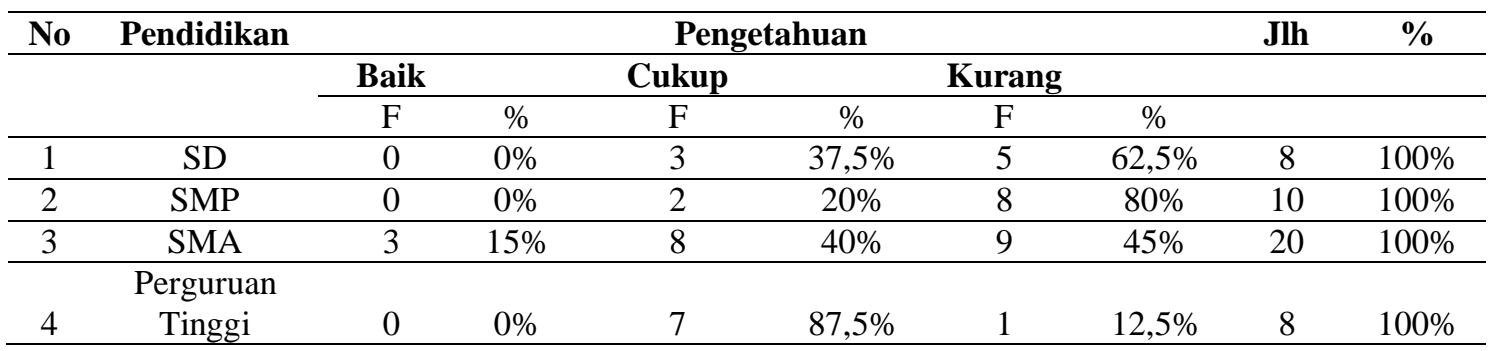

Berdasarkan tabel 2 dapat dilihat dari 46 responden yang berpendidikan SD sebanyak 8 Orang (100\%), dengan kategori cukup 3 orang $(37,5 \%)$, dan kategori kurang 5 orang $(62,5 \%)$. Berpendidikan SMP sebanyak 10 orang (100\%), dengan kategori cukup 2 orang (20\%), dan kategori kurang 8 orang $(80 \%)$. Berpendidikan SMA sebanyak 20 orang $(100 \%)$, dengan kategori baik 3 orang (13\%), kategori cukup 8 orang (40\%), dan kategori kurang 9 orang (45\%). Berpendidikan Perguruan Tinggi sebanyak 8 orang (100\%), kategori cukup 7 orang $(87,5 \%)$, dan kategori kurang 1 orang $(12,5 \%)$. 
Tabel 3. Distribusi Frekuensi dan Persentase Responden Berdasarkan Pekerjaan Tentang Pengetahuan Wanita Usia 45-55 Tahun Tentang Menopause Di Desa Huta Koje Kecamatan Padangsdimpuan Tenggara Kota Padangsidimpuan Tahun 2020.

\begin{tabular}{|c|c|c|c|c|c|c|c|c|c|}
\hline \multirow[t]{3}{*}{ No } & Pekerjaan & \multicolumn{6}{|c|}{ Pengetahuan } & \multirow[t]{3}{*}{ Jlh } & \multirow[t]{2}{*}{$\%$} \\
\hline & & Baik & & Cukup & & Kurang & & & \\
\hline & & $\mathrm{F}$ & $\%$ & $\mathrm{~F}$ & $\%$ & $\mathrm{~F}$ & $\%$ & & \\
\hline 1 & PNS & 0 & $0 \%$ & 7 & $100 \%$ & 0 & $0 \%$ & 7 & $100 \%$ \\
\hline 2 & Wiraswasta & 1 & $6 \%$ & 7 & $47 \%$ & 7 & $47 \%$ & 15 & $100 \%$ \\
\hline 3 & Petani & 1 & $5 \%$ & 4 & $21 \%$ & 14 & $74 \%$ & 19 & $100 \%$ \\
\hline 4 & Tidak Bekerja & 1 & $20 \%$ & 1 & $20 \%$ & 3 & $60 \%$ & 5 & $100 \%$ \\
\hline
\end{tabular}

Berdasarkan tabel 3 dapat dilihat dari 46 responden yang bekerja sebagai PNS sebanyak 7 orang $(100 \%)$, dengan kategori cukup 7 orang (100\%), Bekerja sebagai Wiraswasta sebanyak 15 orang $(100 \%)$, dengan kategori baik 1 orang (6\%), kategori cukup 7 orang (47\%), dan kategori kurang 7 orang (147\%). Bekerja sebagai Petani sebanyak 19 orang (100\%), dengan kategori baik 1 orang (5\%), kategori cukup 4 orang $(21 \%)$, dan kategori kurang 14 orang (74\%). Dan yang Tidak Bekerja sebanyak 5 orang $(100 \%)$, dengan kategori baik 1 orang $(20 \%)$, kategori cukup 1 orang $(20 \%)$, dan kategori kurang 3 orang $(60 \%)$.

Tabel 4. Distribusi Frekuensi dan Persentase Responden Berdasarkan Sumber Informasi Tentang

Pengetahuan Wanita Usia 45-55 Tahun Tentang Menopause Di Desa Huta Koje Kecamatan Padangsdimpuan Tenggara Kota Padangsidimpuan Tahun 2020.

\begin{tabular}{|c|c|c|c|c|c|c|c|c|c|}
\hline \multirow[t]{3}{*}{ No } & \multirow{3}{*}{ Sumber Informasi } & \multicolumn{6}{|c|}{ Pengetahuan } & \multirow[t]{2}{*}{ Jlh } & \multirow[t]{2}{*}{$\%$} \\
\hline & & Baik & & Cukup & & Kurang & & & \\
\hline & & $\mathrm{F}$ & $\%$ & $\mathrm{~F}$ & $\%$ & $\mathrm{~F}$ & $\%$ & & \\
\hline 1 & Media Elektronik & 2 & $25 \%$ & 2 & $25 \%$ & 4 & $50 \%$ & 8 & $100 \%$ \\
\hline 2 & Media Cetak & 0 & $0 \%$ & 0 & $0 \%$ & 7 & $100 \%$ & 7 & $100 \%$ \\
\hline 3 & Petugas Kesehatan & 1 & $3 \%$ & 17 & $55 \%$ & 13 & $42 \%$ & 31 & $100 \%$ \\
\hline
\end{tabular}

Berdasarkan tabel 4 dapat dilihat dari 46 responden yang mendapatkan sumber informasi dari Media Elektronik sebanyak 8 orang ((100\%), dengan kategori baik 2 orang (25\%), kategori cukup 2 orang (25\%), dan kategori kurang 4 orang (50\%). Mendapatkan sumber informasi dari Media Cetak sebanyak 7 orang (100\%), dengan kategori kurang 7 orang (100\%), Mendapatkan sumber informasi dari Petugas Kesehatan sebanyak 31 orang (100\%), dengan kategori baik 1 orang (3\%), kategori cukup 17 orang (55\%), dan kategori kurang 13 orang (42\%).

\section{HASIL DAN PEMBAHASAN}

Mayoritas pengetahuan wanita usia 45-55 tahun tentang menopause adalah kurang yaitu sebanyak 24 orang ( $52 \%$ ) dan minoritas pengetahuan baik yaitu 3 orang $(7 \%)$. Setelah peneliti memberikan penjelasan ternyata wanita yang sudah memasuki usia menopause telah banyak mengabaikan tanda dan gejala menopause. Peneliti memyimpulkan pengetahuan kurang disebabakan karena kurangnya informasi dari tenaga kesehatan tentang menopause serta sulitnya memberikan penyuluhan kepada wanita yang sudah memasuki usia menopause dikarenakan kesibukan masingmasing wanita menopause.

\section{Pengetahuan Responden Berdasarkan Pendidikan}

Berdasarkan tabel 1 mayoritas pengetahuan berdasarkan pendidikan responden berpengetahuan cukup yang berpendidikan perguruan tinggi sebanyak 7 orang $(87,5 \%)$ dan minoritas berpengetahuan baik berpendidikan perguruan tinggi 1 orang (12,\%\%).

Menurut Notoadmdjo (2012), Proses dan kegiatan pendidikan pada dasarnya menimbulkan masalah masalah perilaku individu maupun kelompok. Kenyataan pendidikan formal maupun informal berfokus pada proses belajar mengajar dengan tujuan agar terjadi perubahan perilaku yaitu dari tidak tahu menjadi tahu, tidak dapat menjadi dapat dan tidak mengerti menjadi mengerti.

Hersey dan Blanchard dalam Mulyana (2015), Pendidikan baik formal maupun informal dapat mempengaruhi seseorang dalam mengambil keputusan dan berperilaku.Dengan pendidikan dapat meningkatkan kematangan intelektual sehingga dapat membuat keputusan dalam bertindak. 
Semakin tinggi pendidikan seseorang akan semakin mudah baginya untuk menerima serta mengembangkan pengetahuan dan teknologi.

Menurut asumsi peneliti pendidikan juga mempunyai peranan penting bagi wanita yang memasuki usia menopause karena pendidikan menentukan pengetahuan mereka dalam mengetahui tanda dan gejala menopause dengan salah satu cara menghindari pemicu stress. Peneliti sependapat dengan teori yang dikemukakan di atas karena seseorang berpendidikan lebih tinggi sudah tentu lebih mudah dan lebih banyak memperoleh ilmu dilihat dari jenjang pendidikannya karena seseorang yang berpendidikan rendah akan lebih sedikit mendapat informasi.

\section{Pengetahuan Respnden Berdasarkan Pekerjaan}

Berdasarkan tabel 2 mayoritas pengetahuan berdasarkan pekerjaan responden berpengetahuan cukup yang bekerja sebagai PNS sebanyak 7 orang (100\%), dan minoritas berpengetahuan baik yang bekerja sebagai Petani sebanyak 1 orang $(5 \%)$.

Menurut Woles ( 2009), Pekerjaan dalam arti luas adalah aktifitas utama yang dilakukan manusia. Dalam arti sempit, istilah pekerjaan digunakan untuk suatu tugas atau kerja yang menghasilkan uang bagi seseorang. Dalam pembicaraan sehari-hari istilah ini sering diangggap sinonim dengan profesi.

Menurut Notoadmodjo (2010), Pekerjaan juga sangat mempengaruhi pengetahuan, orang yang sering berinteraksi sosial dengan orang lain akan lebih banyak menerima informasi dan akan semakin banyak pengetahuan jika dibandingkan dengan yang tidak mempunyai pekerjaan.

Asumsi dari hasil penelitian ini maka penelitian ini sesuai dengan teori diatas, ini disimpulkan karena diperoleh responden yang berpengetahuan cukup yang bekerja sebagai PNS lebih sering berinteraksi dengan orang lain dibandingkan dengan yang bekerja sebagai petani yang sepanjang hari berada disawah.

\section{Pengetahuan Responden Berdasarkan Sumber Informasi}

Berdasarkan tabel 3 mayoritas pengetahuan berdasarkan sumber informasi berpengetahuan kurang yang mendapatkan sumber informasi dari media cetak sebanyak 7 orang (100\%), dan minoritas mendapatkan sumber informasi dari petugas kesehatan sebanyak 1 orang (3\%).

Menurut Notoatmodjo (2010), Sumber informasi merupakan kemudahan untuk memperoleh sesuatu informasi dapat mempercepat seseorang memperoleh pengetahuan yang baru. Pekerjaan sangat menentukan terhadap seseorang untuk berbuat sesuatu kegiatan. Dengan adanya pekerjaan, seseorang akan memerlukan banyak waktu dan banyak perhatian. Masyarakat yang sibuk hanya memiliki sedidkit waktu memperoleh informasi.

Asumsi peneliti tentang penelitian ini sependapat karena berkaitan dengan teori di atas hasil penelitian di dapatkan bahwa responden lebih banyak memperoleh pengetahuan cukup dari media cetak.Hal ini disebabkan karena sumber informasi dari media cetak lebih efektif dan efesien dengan membaca informasi lebih muda dipahami.

\section{KESIMPULAN}

Pengetahuan Wanita Usia 45-55 Tahun Tentang Menopause Di Desa Huta Koje Kecamatan Padangsidimpuan Tenggara Kota Padangsidimpuan Tahun 2020 mayoritas pengetahuan wanita usia 45-55 tahun tentang menopause adalah kurang yaitu sebanyak 24 orang ( $52 \%$ ) dan minoritas pengetahuan baik yaitu 3 orang (7\%). Pengetahuan Wanita Usia 45-55 Tahun Tentang Menopause Di Desa Huta Koje Kecamatan Padangsidimpuan Tenggara Kota Padangsidimpuan Tahun 2020 mayoritas pengetahuan berdasarkan pendidikan responden berpengetahuan cukup yang berpendidikan perguruan tinggi sebanyak 7 orang $(87,5 \%)$ dan minoritas berpengetahuan baik berpendidikan perguruan tinggi 1 orang (12,\%\%). Pengetahuan Wanita Usia 45-55 Tahun Tentang Menopause Di Desa Huta Koje Kecamatan Padangsidimpuan Tenggara Kota Padangsidimpuan Tahun 2020 mayoritas pengetahuan berdasarkan pekerjaan responden berpengetahuan cukup yang bekerja sebagai PNS sebanyak 7 orang (100\%), dan minoritas berpengetahuan baik yang bekerja sebagai Petani sebanyak 1 orang (5\%). Pengetahuan Wanita Usia 45-55 Tahun Tentang Menopause Di Desa Huta Koje Kecamatan Padangsidimpuan Tenggara Kota Padangsidimpuan Tahun 2020 mayoritas pengetahuan berdasarkan sumber informasi berpengetahuan kurang yang mendapatkan

JURKESMAS : Jurnal Kesehatan Masyarakat, Vol. 1, No. 1, Juli 2021: 119 - 123 
sumber informasi dari media cetak sebanyak 7 orang (100\%), dan minoritas mendapatkan sumber informasi dari petugas kesehatan sebanyak 1 orang (3\%).

\section{REFERENSI}

Aulia (2009).Tuntas Menstruasi, Yogyakarta : Milestone. Jurnal Cakrawala Kesehatan, Vol. X, No. 01, Februari 2019

Boy Kesuma, (2009). Mengatasi Sindrom Menopause untuk Pasangan Setia : Pustaka Panasia: Yogyakarata

Dr. Wening Sari, M.Kes. dr. Lili Indrawati, M.Kes. Drs. Basuki Dwi Harjanto, M.M (2012). Panduan Lengkap Kesehatan Wanita : Penebar Plus+(Penebar Swadaya Grup) : Wisma Hijau Jl. Raya Bogor Km. 30 Mekarsari, Cimanggis, Depok 16952

Dinas Kesehatan Sumatera Utara, (2018). / Profil Kesehatan Sumatera Utara

Kemenkes RI (2019). Profil Kesehatan Indonesia. Jakarta : Kemenkes RI. https : // myjurnal. Poltekkes-kdi.ac. Id/index. Php/HIJP Volume 12, Nomor 1, Juni 2020

Notoadmodjo, Soekidjo, (2012). Ilmu Perilaku Kesehatan, Jakarta : PT RINEKA CIPTA

Nuswantari Dyah, (2017). Kamus Kedokteran Dorland Edisi 25. Jakarta : EGC

Rosenthal, M.S. (2017) The Gynecplogical Sourcebook : When They Tell You Ist Cancer. USA : Mc. Graw Hill. 272-279.

Rudi Haryono, (2016). Siap Menghadapi Menstruasi dan Menopause : Gosyen Publishing : Yogyakarta Wawan dan Dewi, (2011).Teori Pengukuran, Sikap dan Perilaku Manusia, Yogyakarta : Nuha Medika Wawan dan Dewi, (2019).Teori Pengukuran, Sikap dan Perilaku Manusia, Yogyakarta : Nuha Medika Word Health Organization, (2019) Menopause, http : // www. Who. Int/. http : // myjurnal. Poltekkes-kdi.ac. Id/index. Php/HIJP Volume 12, Nomor 1, Juni 2020 